\title{
IFI44 Gene
}

National Cancer Institute

\section{Source}

National Cancer Institute. IFl44 Gene. NCI Thesaurus. Code C123866.

This gene may play a role in the response to viral infection. 